\title{
Peas and carrots, apples and oranges: Not all malperfusion is the same
}

\author{
Himanshu J. Patel, MD
}

\footnotetext{
From the Section of Adult Cardiac Surgery, Department of Cardiac Surgery, University of Michigan Frankel Cardiovascular Center, Ann Arbor, Mich.

Disclosures: H.J.P. receives consulting fees from Medtronic, Terumo, and W. L. Gore.

Received for publication March 6, 2018; accepted for publication March 9, 2018; available ahead of print April 3 , 2018.

Address for reprints: Himanshu J. Patel, MD, Section of Adult Cardiac Surgery, Department of Cardiac Surgery, CVC, Room 5144, 1500 E Medical Center Dr, SPC 5864, Ann Arbor, MI 48109-5864 (E-mail: hjpatel@med. umich.edu).

J Thorac Cardiovasc Surg 2018;156:25-6

$0022-5223 / \$ 36.00$

Copyright (C) 2018 Published by Elsevier Inc. on behalf of The American Association for Thoracic Surgery https://doi.org/10.1016/j.jtcvs.2018.03.039
}

In a provocative early study, Deeb and colleagues ${ }^{1}$ proposed the notion of an endovascular reperfusion first approach to treat acute type A aortic dissection (ATAD) complicated by severe end-organ dysfunction. This strategy was based on a seminal work by Williams and colleagues ${ }^{2}$ that described the pathophysiology contributing to malperfusion syndrome with aortic dissection. With this background, the Michigan group (of which I am part) has for almost 25 years espoused the notion of delaying operative management for those presenting with acute type A aortic dissection and severe malperfusion syndrome until after resolution of the ischemic insult. The late results of this approach were described in the Journal 10 years ago and suggested that when revascularization was undertaken first, late survival for patients with malperfusion was similar to that of those who presented without malperfusion. ${ }^{3}$ In that study, of the 70 patients with malperfusion, $23(32.8 \%)$ died before open repair; these included 12 deaths $(17.4 \%)$ from aortic rupture and 11 deaths $(15.7 \%)$ from complications associated with the malperfusion syndrome.

In the 2 decades since the initial descriptive study of Deeb and colleagues, ${ }^{1}$ a number of investigators have described results of both immediate and delayed strategies for acute type A aortic dissection with malperfusion, with varying results. The study by the Stanford group reported in this issue of the Journal by Chiu and colleagues ${ }^{4}$ extends this work and espouses an immediate surgical strategy, with acceptable results. In all these evaluations, however, a direct comparison between strategies is lacking. ${ }^{4-8}$

The primary issue that likely contributes to the confusion remains the definition of what constitutes malperfusion. Is it a radiographic finding of reduced enhancement of a vascular bed, which could be confounded simply by poor timing of image acquisition relative to contrast bolus administration? Is it simply the loss of a pulse in an extremity, as described in the current work by Chiu and colleagues ${ }^{4}$ ? Or is it as Deeb and colleagues ${ }^{1}$ described it,

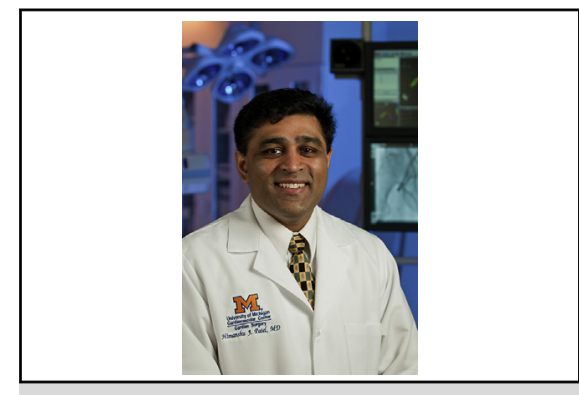

Himanshu J. Patel, MD

Central Message

The jury is still out on the best management strategy for acute type A aortic dissection, delayed operation after endovascular reperfusion versus immediate operation.

See Article page 18

involving significant end-organ dysfunction from prolonged ischemia resulting in hematochezia or limb sensorimotor changes?

The second but equally important issue that contributes to confusion revolves around the vascular beds affected by ischemia. In the experience of my group, malperfusion is assessed not only by clinical means but also by manometric assessment of aortic root to branch vessel gradients. My group's previous study, ${ }^{3}$ which used this approach, found multiple territories to be affected in 40 of 70 patients $(57.1 \%)$; this finding contrasts with the $27 \%$ identified in the report of Chiu and colleagues. ${ }^{4}$

The final contributor to confusion lies in the relative distributions of visceral, renal, or limb malperfusions. For example, the study of Chiu and colleagues ${ }^{4}$ describes 7 patients $(8.5 \%)$ with visceral malperfusion, whereas the previous report of my Michigan group ${ }^{3}$ describes 37 (52.8\%).

The Michigan message has been clear. Operate on all patients with acute type A dissection immediately, unless there is evidence of significant end-organ dysfunction from ischemia. In that case, restore perfusion with an endovascular approach, wait until the ischemia-reperfusion injury has resolved, and then take the patient to the operating room. As far as deciding which strategy should be the criterion standard, as suggested by the Stanford group, until the issues described above are consistently clarified and categorized, we will continue talking about peas and carrots, apples and oranges. They are all fruits and 
vegetables-no real scientific evidence exists to say which is better, and it is all a subjective, opinionated matter of taste.

\section{References}

1. Deeb GM, Williams DM, Bolling SF, Quint LE, Monaghan H, Sievers J, et al. Surgical delay for acute type A dissection with malperfusion. Ann Thorac Surg. 1997; 64:1669-75; discussion 1675-7.

2. Williams DM, Lee DY, Hamilton BH, Marx MV, Narasimham DL, Kazanjian SN, et al. The dissected aorta: part III. Anatomy and radiologic diagnosis of branch vessel compromise. Radiology. 1997;203:37-44.

3. Patel HJ, Williams DM, Dasika NL, Suzuki Y, Deeb GM. Operative delay for peripheral malperfusion syndrome in acute type A dissection: a long term analysis. J Thorac Cardiovasc Surg. 2008;135:1288-95; discussion 1295-6.
4. Chiu P, Tsou S, Goldstone AB, Louie M, Woo YJ, Fischbein MP. Immediate operation for acute type A aortic dissection complicated by visceral or peripheral malperfusion. J Thorac Cardiovasc Surg. 2018;156:18-24.e3.

5. Kamman AV, Yang B, Kim KM, Williams DM, Deeb GM, Patel HJ. Visceral malperfusion in aortic dissection: the Michigan experience. Semin Thorac Cardiovasc Surg. 2017;29:173-8.

6. Ehrlich MP, Ergin MA, McCullough JN, Lansman SL, Galla JD, Bodian CA, et al. Results of immediate surgical treatment of all acute type A dissections. Circulation. 2000;102(19 Suppl 3):248-52.

7. Lauterbach SR, Cambria RP, Brewster DC, Gertler JP, Lamuraglia GM, Isselbacher EM, et al. Contemporary management of aortic branch compromise resulting from acute aortic dissection. J Vasc Surg. 2001;33:1185-92.

8. Geirrson A, Szeto WA, Pochettino A, McGarvey ML, Keane MG, Woo YJ, et al. Significance of malperfusion syndromes prior to contemporary surgical repair for acute type A dissection: outcomes and need for additional revascularization. Eur J Cardiothorac Surg. 2007;32:255-62. 